\title{
Renaissance educational guidelines of the «Ideal governor» training in «Song of the bison» by Belarusian thinker Mykola Husovsky
}

\author{
Dmytro Loboda ${ }^{1}$ \\ ${ }^{1}$ Poltava V.G. Korolenko National Pedagogical University
}

\begin{abstract}
The article is devoted to the coverage of the main Renaissance educational guidelines for the training of the «ideal governor» in the "Song of the bison» by Belarusian thinker Mykola Husovsky, who lived in the XV - XVIth centuries. In particular, author's allusions and metaphors of the words «bison» and «ideal governor», «forest dwellers» and society were analyzed. It was characterized the author 's ideas about the statesman' s training including the necessity of the development of integrity, sincerity, moderation, wisdom, justice etc of a student . At the same time, it was found that a representative of the East Slavic ethno-cultural environment Husovsky was concentrated on a common European humanistic mainstream. This is specified in the inheritance of titles and regalia, honor and high morality, aesthetization and liberalization of educational influences on the individual in the conditions of constant independent hard work over the representatives of the political establishment of that time in Europe.
\end{abstract}

Keywords: allusion, hedonism, humanism, aesthetic education, metaphor, morality, «Song of the bison», virtues, nobility.

\section{The statement of problem}

The current horizons of the Ukrainian world today require new assessments not only the role of a person in history, the role of the discoverer, the role of the harbinger or announcer of the fateful idea, the commander or the helmsman, but also the illumination of the role of a master minder and the patron - educator or teacher, whose educational influence has become the producer of human progress. More than ever, the problem of governors, statesmen and officials' training of different levels is acute these days. Nowadays, a formalized approach isn't enough for human resources of the country; the actualities of the renaissance education of «from the cradle» statesmen have matured in a new way.

In previous publications we have provided the results of explorations of Western European and Ukrainian practices and programs of training of «ideal governors» through the analysis of the philosophical and pedagogical heritage of the Renaissance thinkers. The publication of new sources of the East European cultural and historical history in XIV - XVI centuries made it possible to review the place and role of representatives of the Belarusian ethnic group in the new European development of conceptual landmarks of elite education.

\section{Assignment of previously unresolved parts of a common problem}

All the above-mentioned in the article we decided to refer to the memorial of literature of the XVI century «Song of the bison» («Poem about the bison»), which was written by the famous poet and thinker of Belarusian origin Mykola Husovsky (1470-1533) approximately in 1523 year.

The author of this famous poem was born in the Grand Duchy of Lithuania in a family of a hunter, watching the natural beauties of modern Polish and Belarusian border. In full riot of the European Reformation movement, he was ordained a Catholic priest, so his professional activity required constant traveling. He experienced significant renaissance influences while on various missions in Italy, in particular the Papal Curia. There he started writing the poem that was devoted to Pope Leo X. However, after the death of the latter Husovsky had to finish his writing in Krakow, and the object of dedication became Bono Maria Sforza d'Aragon, the Queen of Poland and mother of Sigismund II August [7].

It is not known whether the poem reached the addressee, but the humanistically colored instructions, which were apparently intended not only for Bona as the actual governor of the country but also for her son, the future king, had a catastrophic effect. It is a great interest for the modern researcher. 


\section{Formulation of the goals of the article}

The purpose of our research was to analyze and characterize the main Renaissance educational guidelines of the «ideal governor» training in «Song of the bison» by Belarusian thinker Mykola Husovsky.

\section{Analysis of recent research and publications}

Some aspects of Mykola Husovsky's work are shown in the articles by Ukrainian researchers, in particular, Slipushko O., Klyosova O. By the way, Trofimuk articles are devoted to bring the heritage of the Eastern Slavic thinker into the Ukrainian historical context of the day. In turn, O. Shchelkunov is interested in the linguistic side of the research potential of «Poem on the Bison» as a memorial of Russ of Renaissance literature.

Belarusian researchers, including V. Bolbas and K. Buslov, note that in his poem Mykola Husovsky made a metaphorical allusion between the protagonist, the bison, and actually the ideal prince. The author endowed him with soul, pride, animal conscience. The image of a forest hero is a personification of strength, courage and nobility, skillfully grinds the personality of a veiled helmsman whom the thinker wanted to see during his life. The process of creating a moral ideal is noticeable in the characters of the common people. They are resourceful, clever, courageous people, who are faithful to their own Fatherland. The artistically described portrait of the ideal person has absorbed a wide palette of pan-European axiological and ethical attitudes of the world, the morality of the civil service of the people, humanistic upbringing, democracy and patriotism, which shed light on the illumination of the way out of the past ( and present) spiritual despair.

\section{Statement of the main research material}

Mykola Husovsky, who paid considerable attention to the problems of moral education, was famous Belarusian poet, author of one of the most striking works of East Slavic secular literature in the 16th century, which is called «Song of the bison». Closer communication with the common people enabled him to go deeper than his contemporary Franciszek Skoryna to connect moral and ethical theorizing with real life, to enrich it with elements of everyday reality. It is fundamental to consider Mykola Husovsky approach to the assessment of moral education, which he formulated in the well-known words today: «The state relies more on the courage of the spirit than on the strength of the body» [3, p. 13, 14].

As you can see from the pages of the poem of the thinker, both happiness and glory are considered as a consequence of high spirituality. He thought about the meaning of human existence and came to the conclusion that man is the most important creation of God and designed the entire educational system so that everyone would be happy: «There is nothing on earth that would not be created for happiness - every person admires something; every person gets benefits from everything» [5, p. 47, 48]. These lines also traced with the humanist's thoughts about the epicurean thirst for pleasure. However, Mykola Husovsky does not dwell on narrowly utilitarian, hedonistic approaches in defining the meaning of human being: all his works go through the idea of the necessity of orientation towards the public kindness and the thesis that a person can perpetuate his own name only with the merits of the community. A sense of obligation to people as one of the main criteria of morality is the leitmotif of all literary creativity of the Belarusian poet [2, p. 61 , 62].

The poet considered the origin of the majority of social disasters as a failure of people who ignore moral laws written by their ancestors. He wrote: «It would be better for people to seal in their memory all ancestors` experience» [1, p. 84]. In his opinion, the moral and spiritual improvement of society would help to prevent the Tatar and Turkish invasion of Europe, to overcome the plague and to carry out a number of other destructions that people expected from God. The position of Mykola Husovsky was very modern in its protestant, even somewhat atheistic colour. Observations on the everyday life of ordinary people gave the thinker reason to believe that in the end, the person is the creator of his or her own destiny: «You do your business with your own hands and hold your own wood in them» [6, p. 124, 125].

Husovsky was confused because of the causes of low levels of morality in society, the instability of faith. Even Christ, who was sent by God for the salvation of mankind, «... still could not take the right path of the instruction ...» [4, p. 31]. He considered that one of the reasons for this failure was lack of a well-defined purpose of educational activity: «People believed, but they waited for the purpose, whether the primary sources could be seen» [4, p. 36]. 
Therefore, the poet tried as an educational goal to create the perfect image as a representative of the highest status, and just a man.

The standard of the statesman, leader and educator in his work was Prince Vytautas, whom Mykola Husovsky drew as a multi-faceted person. He gave the prince a number of traits: justice, wisdom, moderation, mercy, generosity, erudition, etc. Paying attention to the role of the tutor, the author of the famous poem we have to add that he especially emphasized that one of the merits of the prince was his permission to govern at different levels of representatives of different parts of society. Vytautas encouraged his people to kind actions, which led to «... the highest prosperity of the Principality of Velikolitovsky» [9, p. 116].

Demonstrating an example of ethical excellence, the humanist has uncovered a system of axiological guidelines that should be in harmony with each person's aspirations. Husovsky's patriotism is one of the qualities that does not depend on the status of the owner. The ethical doctrine of the thinker specifically identifies the attempt to separate the nobility from the noble origin. For example, according to his idea, honor can be acquired only by the person himself, not by inheritance. The «crystallization» of Husovsky's idea of «acquired» nobility came about under the influence of Erasmus Vitellius, a well-known politician and public figure, his trustee of childhood, who was always reproached for the insignificance of origin, to which he replied: «... not your name gives you fame but hard work» [3, p. 15].

Mykola Husovsky believed that the most important task of moral education is the formation of personal sociable skills. He emphasizes the benefits of social lifestyles on the example of a herd of bison. The power of the bison is reduced by several times, only it is reflected from the relatives: the same is transferred by the author to the human society: «... lonely person is not able to show their traits ..." [8, p. 157]. Active civic life, accordingly, acquires educational value, serves as an element of education of the personality of the steering. With the help of society, an individual can achieve moral «results».

Mykola Husovsky didn't limit morality in the training of the future governor. He emphasized on the education of «servants of the society» and the studying of the sciences with books, distinguished life and work experience. He recommended to coordinate and reconcile theoretical knowledge with real life, because detached theory from life can lead to irreparable losses and mistakes or you don't get any results. Such attitude to education can be seen in the lines: «It is strange that the bison is not accurately described in books» [4, p. 15]. It means that Husovsky knew forest dwellers well not only from the pages of books but also constantly saw them in real because his father was a hunter. For book lovers dense forest is a mystery, and the thinker has warned them: answers to many questions «... you will not find into books» and solving all the mysteries «... hide in the forest» [7].

The patriotic orientation of morality, which is built on the intellectual base, requires the active life position of the child-heir: «... in the sun there was not a single moment without struggle on earth and there will not be» [1, p. 86]. Therefore, in order to overcome difficult life obstacles, according to Husovsky idea, there is a true spiritual selfdevelopment and personality formation. He praised the state importance of Vytautas educational camps, where people were physically and mentally tempered, through special didactic means and techniques. They developed excellent moral qualities, were deprived of negative habits and destructive aspirations [3; 9, p. 116, 117].

The thinker realized that it was difficult to bring up all the necessary set of qualities of the «ideal governor» right away and warned about the need for constant hard work for the benefit of the person: «Simple steps lead to the top» [5, p. 46]. He also warned that certain qualities of a person may be revealed differently in the course of their life. For example, a brave young man cannot always show his courage, for example, when a young man «... only if he fancies his beloved he can lose control - and immediately die» [4, p. 54].

Even having educated the elite of the nation, Mykola Husovsky offered not to give up the educational opportunities that nature opened up. In fact it was like «school» of his life, which educates the humanity in the person: «.. the elixir of youth and pep» [2, p. 63]. Forest, physical labor, hunting are invaluable sources for the soul and body of a person.

Humanism and humanistic values in this context, more than ever, clearly demonstrate the author's mental quidelines for pan-European civilization progress. The rational relations between people and nature, the prohibition of hunting for females and their brood, the careful attitude to natural resources can be compared with the world of human, society and the state in general.

Mykola Husovsky focused his readers' attention on aesthetic education as well, because having confronted with beauty and grandeur, a person is enriched no less than the previous one. Since the main focus of artistic life was still the church at the time, the thinker recommended that «... shrines be more attractive because the temple majesty is able to enlighten the mind of the inexperienced people» [3, p. 17]. That importance was given to different types of art: «Gusli and songs are enchanting and have a terrible power» [4, p. 93].

Like all prominent figures of the Renaissance, the poet attributed verbal influence on the child to the key methods of education. He compared the pen of a poet with an arrow in the hand of a clever warrior, because with the word it can lead to both the virtue and the decay of the human soul. Mykola Husovsky singled out encouragement and 
punishment as one of the effective methods of education. These elements were important not only for their influence on the pupil, but also as an example for the further management of subjects. They were cleverly used by Vytautas, who rewarded the best for his services, while at the same time punishing for justice. Like Skoryna, he paid attention to education of the example and wrote that the future helmsman is much easier to bring up the names and stories of famous people and noble heroes-countrymen. In this case, preference was given not to biblical or ancient characters, but rather to national ones, as the most simple and understandable [2, p. 61].

According to Mykola Husovsky, the presence of socially significant guidelines, awareness of the need for high moral behavior is a primary and necessary condition for the development of each person. That is why the author of «Song of the Bison» set out to create perfect images of both the higher states and the people in general. For example, the model of the «statesman» for the poet was a person who was endowed with such traits as reason, nobility, justice, demandingness, harshness, responsiveness to his subordinates.

\section{Results of the research and perspectives}

We summarize that the metaphorical allusions of Mykola Husovsky from bison to the «ideal governor», from forest dwellers to society, can be described as a pan-European humanist trend, which the author transferred to his native East Slavic roots.

The European ideas of the author about the concepts of «ideality», «upbringing», «wisdom» etc. are consistent with the ancient notions of virtue, absorbing, above all, the whole range of Renaissance virtues from justice to sincerity. The humanist put on the agenda the issue of spiritual and moral improvement of personality beyond the influence of only the church clergy, in fact departing from the orthodoxy to which he belonged. At the same time, he argued that the fundamental components of a high moral personality, such as honor, cannot be inherited, but are acquired only in the process of long hard work and overcoming difficult obstacles. Not forgetting the variability of the ways of human development in various educational influences on it, the humanist promoted some methods of «soft hand», because they, as a result, will contribute to the non-violent, peaceful character of the secular ruler, and one of the tools of humanity offered art and worship beauty, always reminding us about the beauty of nature and natural things.

\section{References}

[1] Bolbas, V.S. (1996). Idei moralnoho vykhovannia pedahohichnoi dumky epokhy Vidrodzhennia v Bilorusi (XVI - XVII st.) [Ideas of moral education of the pedagogical thought of the Renaissance in Belarus (XVI - XVII centuries)]. Minsk: NIA [in Belorussian]

[2] Bolbas, V.S. (1992). Dobri manery dzherela: F. Skoryna ta Mykola Husovsky pro moralne vykhovannia. Navchannia ta vykhovannia [Good manners source: F. Skorina and Mykola Husovsky about moral education]. Education and upbringing [in Belorussian]

[3] Bolbas, V.S. (1992). Moralnyi ta vykhovnyi potentsial spadshchyny Mykoly Husovskoho. [The moral and educational potential of Mykola Husovsky's heritage]. Belarusian Literature: A Republican Interagency Collection. Minsk: University [in Belorussian]

[4] Husovskyi, M. (2007). Pisnia pro zubra. Poema. Na latynskii ta staroukrainskii movakh. [Song about the bison. Poem. In Latin and Old Ukrainian]. Rivne: Volynski oberehy [in Latin and in Ukrainian].

[5] Yz ystoryy fylosofskoi y obshchestvenno-polytycheskoi mysly Belorussyy. (1962). [From the history of the philosophical and socio-political thought of Belarus.] Yzbrannye proyzvedenyia 16 - nachala 19 vv . Mynsk: Yzd-vo AN BSSR [in Russian]

[6] Konon. V.M. Podokshyn, S.A. (1977). Ydey humanyzma v obshchestvenno-polytycheskoi y fylosofskoi mysly Belorussyy [Ideas of humanism in the socio-political and philosophical thought of Belarus.] Mynsk: Nauka y tekhnyka, 1977. 279 s. [in Russian]

[7] Slipushko O., Klosova O. (2020). Mykola Husovskyi: poet, dyplomat, polityk [Mykola Gusovsky: poet, diplomat, politician]. Vseukrainska hazeta «Den»: website URL: http://incognita.day.kyiv.ua/mikola-gusovskij-poet,-diplomat,-politik.html (accessed: 03.02.2020) [in Ukrainian]

[8] Slipushko, O.M. Shchelkunova, O.S. (2019). Mykola Husovskyi: poet i myslytel doby Ukrainskoho Renesansu. [Mykola Husovsky: poet and thinker of the Ukrainian Renaissance] Literatura. Folklor. Problemy poetyky. K.: KNU imeni T. Shevchenka [in Ukrainian]

[9] Trofymuk Myroslav. (2009). Ukrainska pisnia na Vkrainskyi lad [Ukrainian song on the Ukrainian system] Slovo i Chas [in Ukrainian] 